\title{
Ijtihad Progresif dalam Penegakan Hukum Positif Islam di Pengadilan Agama tentang Pembagian Harta Bersama
}

\author{
Akhmad Khisni \\ Fakultas Hukum Universitas Islam Sultan Agung (Unissula) Semarang \\ Jl. Raya Kaligawe Km. 4 Po. Box. 1054 Semarang 50012 \\ khisni@gmail.com
}

\begin{abstract}
The main problems discussed are: First, how the realization of the Islamic positive law reinforcement is in the Religious Court to create justice in the division of marital property in KHI (Islamic Law Compilation); second, what the form of of progressive ijtihad is in the Islamic positive law reinforcement in the Religious Court to create justice in the division of marital property in KHI (Islamic Law Compilation). This research uses normative juridical, descriptive in nature, through the data in form of Religious Court decisions using constructivism paradigm with qualitative analysis. The result of the research is as follows: First, in the division of marital property, the wife gets $2 / 3$ (two-thirds) which is more than the husband who gets 1/3 (a third). This decision seems contradicting Article $97 \mathrm{KHI}$. Second, using the method ijtihad tatbiqi, ijtihad used in implementing the law by observing the facts and events as the background of the case, the judges find the appropriate clauses for the case after observing the relations between the background facts and event.
\end{abstract}

Key words : Ijtibad, religious court, marital property.

\begin{abstract}
Abstrak
Masalah pokok yang diteliti adalah: Pertama, bagaimana wujud penegakan hukum positif Islam di Pengadilan Agama untuk mewujudkan keadilan dalam pembagian harta bersama dalam Kompilasi Hukum Islam (KHI); kedua, apa bentuk ijtihad progresif dalam penegakan hukum positif Islam di Pengadilan Agama untuk mewujudkan keadilan dalam pembagian harta bersama dalam Kompilasi Hukum Islam (KHI).Penelitian ini menggunakan pendekatan yuridis normatif, bersifat deskriptif, melalui data berupa putusan Pengadilan Agama, dengan paradigma studi konstruktivisme, menggunakan analisis kualitatif. Adapun hasil penelitian sebagai berikut: Pertama, dalam pembagian harta bersama istri mendapatkan 2/3 (dua pertiga) lebih besar dibanding dengan suami yang mendapatkan 1/3 (sepertiga), putusan ini seolah- olah bertentangan dengan Pasal $97 \mathrm{KHI}$. Kedua, dengan metode iitihad tatbiqi, yaitu ijtihad dalam penerapkan hukum dengan melihat fakta dan peristiwa yang melatar belakangi kasus tersebut, lalu hakim setelah memperhatikan segala hubungan keterkaitannya langkah berikutnya mencarikan hukum yang tepat untuk kasus tersebut.
\end{abstract}

Kata kunci : Ijtihad, peradilan agama, harta bersama. 


\section{Pendahuluan}

Al-Qur'an telah selesai pewahyuannya, demikian juga as-Sunnah telah selesai juga sesudah wafat Rasulullah SAW. Kompilasi Hukum Islam (KHI) pun telah selesai dengan pengundangannya, melalui Instruksi Presiden RI No. 1 Tahun 1991. Di dalam hukum Islam dinyatakan: "an-nushush mutanahiyah" (teks telah selesai) bersifat normatif, deduktif dan tekstual, juga disebut "solen". Di sisi lain, kehidupan manusia (muslim) selalu dinamis, tidak akan selesai yang menyangkut segala aspek kebutuhan hidupnya, baik yang menyangkut hukum dan lainnya, yang dapat dinyatakan:"al-waqa'iq ghairu mutanahiyah"(kejadian-kejadian tidak pernah selesai) selalu dinamis, bersifat empiris, induktif, kontekstual, dan kasuistis, yang disebut: "sein".

Kehidupan yang serba kompleks ini tidak pernah berakhir perubahan dan dinamikanya dan yang abadi itu perubahan dan dinamikanya itu sendiri. Hukum yang sudah dibuat dalam bentuk undang-undang atau hukum Islam dalam produk akal akan selalu kondisional dan ketinggalan atas perubahan dan dinamika kehidupan masyarakat yang dialaminya. Hukum Islam dalam hal ini Kompilasi Hukum Islam (KHI) tidak pernah dapat tuntas menjawab permasalahan hukum yang terjadi di dalam masyarakat, atau dengan kata lain hukum telah selesai pembuatannya, tetapi kehidupan tidak pernah selesai perubahan dan dinamikanya. Apakah Kompilasi Hukum Islam (KHI) yang telah selesai pembuatannya itu dapat menjawab persoalan hukum masyarakat yang tidak pernah selesai. ${ }^{1}$

Untuk dapat menjawab persoalan di atas perlu pengembangan hukum Islam dan pentingnya atau relevansinya ijtihad. Ini dapat dilihat di awal kebangkitan Islam, umat Islam memperlihatkan semangat ijtihad yang tinggi dan berdasarkan kepada keahlian di bidang hukum Islam. Sejalan dengan itu, maka tiga setengah Abad pasca wafatnya Rasulullah SAW merupakan periode formatif bagi hukum Islam. Kendali perkembangan hukum Islam yang pesat tersebut berada di tangan para mujtahid yang tangguh dan andal dalam bidang ini. ${ }^{2}$

${ }^{1}$ A. Khisni, “Transformasi Hukum Islam ke dalam Hukum Nasional (Studi Ijtihad Hakim Peradilan Agama tentang Pengembangan Hukum Kewarisan dalam Kompilasi Hukum Islam dan Kontribusinya terhadap Hukum Nasional”, Program Doktor Ilmu Hukum Universitas Islam Indonesia, Yogyakarta, 2011, hlm. 295.

2 A. Khisni, Metode Ijtihad dan Istinbath, Ijtihad Hakim Peradilan Agama, Cet. 1, Unissula Press, Semarang, 2011, hlm. 2 . 
Dengan demikian, maka dinamika hukum Islam sesungguhnya terletak pada kontak antara faktor dinamika, kreativitas, keahlian para ulama, serta faktor metodologi yang mereka gunakan. Ketiga faktor tersebut telah berjalan harmonis sepanjang sejarah pembentukan hukum Islam masa tiga setengan Abad setelah wafat Rasulullah. ${ }^{3}$

Seiring dengan tuntutan keadaan pada abad modern ini, orang sudah semakin mendambakan sebuah sistem hukum dan perangkat-perangkatnya yang dapat memenuhi tuntutan mereka, maka perumusan metodologi ijtihad yang kontekstual menjadi hal yang tidak dapat ditawar-tawar lagi. Kemampuan untuk mengembangkan ide-ide Kompilasi Hukum Islam (KHI) terutama seorang ahli hukum Islam atau seorang hakim agama berhadapan dengan masalah-masalah baru, akibat dari perubahan dan perkembangan sosial di kalangan umat Islam. Model ahli hukum Islam yang independen, baik dalam metodologi maupun dalam hasil ijtihad, serta memfungsikan warisan fikih mazhab-mazhab, ia tidak terikat mazhab tertentu dan dalam ijtihad memecahkan masalah baru ia memakai metode ushul fikih gabungan dari berbagai gabungan dari berbagai aliran, sanggup memilih mana yang lebih relevan dengan masa kini. ${ }^{4}$

Untuk menjawab kesenjangan antara solen dan sein antar hukum pembagian harta bersama yang terdapat dalam Kompilasi Hukum Islam (KHI) dengan kenyataan melalui putusan atau ijtihad hakim Peradilan Agama yang menimbulkan permasalahan, maka penting untuk dilakukan penelitian untuk mendapatkan jawaban untuk memecahkan permasalahan dengan melakukan ijtihad. Berdasarkan latar belakang masalah tersebut di atas, dipandang perlu diadakan suatu penelitian.

\section{Rumusan Masalah}

Bertitik tolak dari uraian latar belakang masalah tersebut di atas, maka masalah pokok yang penulis teliti adalah: Pertama, bagaimana wujud penegakan hukum positif Islam di Pengadilan Agama untuk mewujudkan keadilan dalam pembagian harta bersama dalam Kompilasi Hukum Islam (KHI); kedua, apa bentuk ijtihad progresif dalam penegakan hukum positif Islam di Pengadilan Agama untuk

\footnotetext{
${ }^{3}$ Ahmad Tholabi Kharlie, Al-Syaukani: Profil Pembaru Pemikiran Hukum Islam, dalam Mimbar Hukum No. 53 Tahun. XII 2001, hlm. 79.

${ }^{4}$ Satria Effendi M. Zein, Pendidikan Syari'ah di IAIN dan Pembinaan Sikap Independen dalam Hukum Islam, dalam Mimbar Hukum No. II Tahun. IV 1993, hlm. 29.
} 
mewujudkan keadilan dalam pembagian harta bersama dalam Kompilasi uukum $\operatorname{Islam}(\mathrm{KHI})$.

\section{Tujuan Penelitian}

Adapun tujuan yang ingin dicapai dalam penelitian ini adalah secara umum untuk menemukan bentuk ijtihad progresif pada penerapan (aplikasi) Kompilasi Hukum Islam (KHI) dalam bidang pembagian harta bersama melalui putusan Pengadilan Agama. Adapun secara khusus adalah Pertama, mengkaji wujud penegakan hukum positif Islam di Pengadilan Agama untuk mewujudkan keadilan dalam pembagian harta bersama menurut Kompilasi Hukum Islam (KHI). Kedua, untuk mengetahui bentuk ijtihad progresif dalam penegakan hukum positif Islam di Pengadilan Agama untuk mewujudkan keadilan dalam pembagian harta bersama dalam dalam Kompilasi Hukum Islam (KHI)

\section{Metode Penelitian}

Penelitian ini bersifat kualitatif dengan menggunakan pendekatan yuridis normatif. Semua data diambil melalui bahan-bahan kepustakaan yang berkaitan dengan obyek penelitian, baik melalui Kompilasi Hukum Islam (KHI) maupun melalui putusan (yurisprudensi) hakim Peradilan Agama, Pengadilan Tinggi Agama, maupun Mahkamah Agung Republik Indonesia, dengan paradigma studi konstruktivisme, untuk selanjutnya dituangkan dalam pembahasan yang logis, sistematis dan komprehensif.

Penelitian ini termasuk penelitian hukum yang normatif, dilakukan analisis induktif, prosesnya dimulai dari premis-premis yang berupa hukum positif Islam (Kompilasi Hukum Islam) yang diketahui. Untuk menemukan hukum bagi suatu kasus nyata (perkara in concreto), norma hukum inabstracto diperlukan untuk berfungsi sebagai premis mayor, sedangkan fakta-fakta yang cocok (relevan) dalam kasus posisi (perkara / legal facts) dipakai sebagai premis minor, melalui proses sillogisme didapatkan sebuah conclusio (kesimpulan) berupa hukum positif yang dicari. ${ }^{5}$

\footnotetext{
${ }^{5}$ Ronny Hanityo Soemitro, Metodologi Penelitian Hukum, Cet. 1, Ghalia Indonesia, Jakarta, 1982, hlm. 10.
} 


\section{Hasil Penelitian dan Pembahasan}

\section{Wujud Penegakan Hukum Positif Islam di Pengadilan Agama}

Kasus Posisi: ${ }^{6}$ Pemohon Kasasi (isteri) dahulu sebagai Penggugat telah mengajukan gugat cerai terhadap Termohon kasasi dahulu (suami) sebagai Tergugat di depan persidangan Pengadilan Agama Yogyakarta pada pokoknya mengajukan dalil-dalil dan bukti-bukti atas gugatannya tersebut. Adapun isi (petitum) gugatan Penggugat adalah menjatuhkan talak satu ba'in dan menyatakan perkawinan antara Penggugat dengan Tergugat putus karena perceraian dan menetapkan secara hukum separuh bagian masing-masing dari keseluruhan harta bersama tersebut sebagai bagian dan hak Penggugat dan Tergugat.

Adapun putusan Pengadilan Agama Yogyakarta amarnya berbunyi: Mengabulkan gugatan Penggugat sebagian, memutuskan perceraian Penggugat dari Tergugat dengan talak satu ba'in shughro dan menetapkan bagian Penggugat dan Tergugat masing-masing memperoleh separuh bagian dari harta bersama. Putusan tersebut dalam tingkat banding atas permohonan Penggugat telah dikuatkan oleh Pengadilan Tinggi Agama Yogyakarta. Dari putusan tersebut Penggugat mengajukan permohonan kasasi yang menguasakan kepada kuasa hukumnya melalui Pengadilan Agama Yogyakarta.

Adapun alasan-alasan yang diajukan oleh Pemohon kasasi/Penggugat dalam memori kasasinya tersebut pada pokoknya adalah bahwa Pengadilan Tinggi Agama Yogyakarta tidak menyertakan penilaiannya terhadap dalil-dalil Pembanding dalam pertimbangan hukumnya untuk kemudian diperbandingkan (dianalisis) dengan alasan Pengadilan Agama Yogyakarta yang karena Pemohon kasasi tidak dapat mengetahui apa yang menjadi alasan dan dalil-dalil teoritik dan aturan hukum positif di dalam menentukan putusan itu, namun demikian telah menunjukkan tidak sesuainya dengan ketentuan Pasal 23 Undang-Undang No. 14 Tahun 1970 sehingga kurang menghormati asas Audi et Alteram Partem yang mengharuskan pengadilan untuk memberikan penilaian yuridis dan akademis terhadap alasan dan dalil-dalil para pihak secara proporsional dan obyektif.

${ }^{6}$ Putusan Pengadilan Agama Yogyakarta, No. 280/Pdt.G/2002/PA.Yk,tertanggal 16 September 2003 M, bertepatan dengan tanggal 19 Rajab 1424 H.Jo. Putusan Pengadilan Tinggi Agama Yogyakarta, No. 36/Pdt.G/2003/ PTA.YK, tanggal 21 Januari 2004 M, bertepatan dengan tanggal 30 Dzulqo’idah 1424 H. Jo. Putusan Mahkamah Agung RI No. 193 K/AG/2004, tanggal 21 Pebruari 2007. 
Bahwa putusan Pengadilan Agama Yogyakarta yang dikuatkan Pengadilan Tinggi Agama Yogyakarta telah mendasarkan pada dalil bahwa isteri adalah merupakan sekutu bagi seorang suami dalam menjalankan bahtera kehidupan (syarikatan rajuli fil hayah), maka terjadi syarikat abdan dan syarikah mufawwadah, sehingga selama perkawinan harta yang diperoleh adalah harta syirkah yang harus dibagi dua antara suami dan isteri yang diperkuat dengan dalil yang merujuk pada al-Qur'an Surat al-Baqarah ayat 228 yang intinya pada wanita mempunyai hak yang seimbang dengan kewajibannya menurut cara yang makruf, demikian mendasarkan ketentuan kitab Syarqowi Alat Tahrir halaman 109 yang intinya apabila terjadi syirkah pada suatu masa tertentu setelah berpindah dan tidak diperbolehkan pada masingmasing syirkah itu, maka harta tersebut dibagi dua.

Alasan diajukannya kasasi bahwa dari paradigma hukum demikian terlihat Pengadilan Agama Yogyakarta yang dikuatkan Pengadilan Tinggi Agama Yogyakarta dalam putusannya telah mengabaikan hak-hak dan prestasi Penggugat sebagai isteri yang telah terbukti memiliki peran lebih besar dengan pengelolaan dan pengembangan perusahaan dari keterangan sejumlah saksi Penggugat yang memiliki relevansi yuridis materiil menjadi diabaikan penilaiannya yang mengemukakan soal mengenai modal perusahaan yang lebih besar dibanding Tergugat/Termohon kasasi.

Menimbang bahwa terhadap alasan-alasan tersebut di atas Mahkamah Agung berpendapat: bahwa alasan-alasan tersebut tidak dapat dibenarkan, karena Yudex facti tidak salah menerapkan hukum, lagi pula hal ini pada hakikatnya mengenai penilaian hasil pembuktian yang bersifat penghargaan tentang suatu kenyataan, hal tersebut tidak dapat dipertimbangkan dalam pemeriksaan pada tingkat kasasi, karena pemeriksaan dalam tingkat kasasi hanya berkenaan dengan adanya kesalahan dalam penerapan hukum, adanya pelanggaran hukum yang berlaku, adanya kelalaian dalam memenuhi syarat-syarat yang diwajibkan oleh peraturan perundangundangan yang mengancam kelalaian itu dengan batalnya putusan yang bersangkutan atau pengadilan tidak berwenang atau melampui batas wewenangnya sebagaimana yang dimaksud dalam Pasal 30 Undang-Undang No. 14 Tahun 1985 Tentang Mahkamah Agung sebagaimana telah diubah dengan Undang-Undang No. 5 Tahun 2004.

Menimbang, bahwa terlepas dari pertimbangan tersebut di atas menurut pendapat Mahkamah Agung amar putusan Pengadilan Tinggi Agama Yogyakarta 
yang menguatkan putusan Pengadilan Agama Yogyakarta harus diperbaiki sepanjang mengenai ketetapan pembagian harta bersama bagi Penggugat dan Tergugat dengan pertimbangan sebagai berikut. Bahwa keterangan saksi-saksi yang diajukan oleh Penggugat kurang dipertimbangkan oleh judex facti, di mana harta bersama tersebut sebagian besar didapat dari hasil kerja keras Penggugat dalam pengelolaan dan perkembangan perusahaan. Sedangkan Tergugat kurang aktifitasnya dalam pengelolaan dan pengembangan usaha tersebut. Oleh karenanya dipandang proporsional dan adil apabila terhadap harta bersama tersebut dibagi berdasarkan seberapa banyak kontribusinya dalam menghasilkan harta bersama tersebut, yakni: 2/3 (dua pertiga) untuk Penggugat (istri) dan 1/3 (sepertiga) untuk Tergugat (suami).

Dalam Kompilasi Hukum Islam (KHI) Pasal 88 dinyatakan: “Apabila terjadi perselisihan antara suami isteri tentang harta bersama, maka penyelesaian perselisihan itu diajukan kepada Pengadilan Agama". Adapun norma hukum yang mengatur harta bersama apabila terjadi perceraian, khususnya cerai hidup diatur dalam Kompilasi Hukum Islam (KHI) Pasal 97 yang dinyatakan: “ Janda atau duda cerai hidup masing-masing berhak seperdua dari harta bersama sepanjang tidak ditentukan lain dalam perjanjian perkawinan".

Adapun putusan Mahkamah Agung seolah-olah bertentangan dengan Pasal 97 KHI di atas yang tidak memutuskan membagi harta bersama masing-masing antara suami dan isteri berhak seperdua (1/2), bahkan Mahkamah Agung memutuskan dalam pembagian harta bersama tersebut, yaitu 2/3 untuk isteri dan $1 / 3$ untuk suami, dengan pertimbangan hukum sejauh mana kontribusi masing-masing dalam membentuk harta bersama tersebut. Dalam hal kasus ini ternyata isteri lebih besar kontribusinya dalam menghasilkan harta bersama tersebut, sehingga wajar apabila bagian isteri lebih besar (2/3) dibanding bagian suami (1/3).

Pengadilan dalam membuat putusan selalu diawali dengan: "Demi Keadilan Berdasarkan Ketuhanan Yang Maha Esa", jadi yang ditegakkan oleh pengadilan adalah "keadilan" bukan "Demi hukum". Beda antara demi keadilan dengan demi hukum, sebab ruh hukum adalah keadilan. Keadilan dalam hal ini dimaknai memberikan kepada setiap orang apa yang menjadi haknya. Dalam teori ilmu hukum dibedakan adanya dua macam keadilan, yaitu: pertama, keadilan distributif, yaitu memberikan kepada setiap orang berdasarkan kontribusinya. Jadi memberikan kepada setiap orang apa yang menjadi haknya berdasarkan kepada asas 
keseimbangan. Kedua, keadilan komulatif, yaitu memberikan kepada setiap orang bagian yang sama. Jadi memberikan kepada setiap orang apa yang menjadi haknya berdasarkan asas kesamaan.

Apabila keperluan rumah tangga diperoleh karena usaha bersama antara isteri dan suami, maka dengan sendirinya harta yang diperoleh selama perkawinan menjadi harta bersama. Besar atau kecilnya harta yang menjadi bagian suami atau isteri tergantung banyak atau sedikitnya usaha yang mereka lakukan dalam memenuhi kebutuhan rumah tangga itu. Kalau suami lebih banyak usahanya dari pada isterinya, maka hak suami juga lebih besar daripada hak isteri, demikian sebaliknya apabila usaha isteri lebih besar daripada suami, maka haknya atas harta bersama juga lebih besar dari suaminya. Bahwa terhadap ketentuan dalam Pasal 97 KHI, maka Pengadilan Agama berpendapat harus diartikan sepanjang harta bersama itu didapat dari hasil usaha suami dan isteri secara berimbang sama besar, baik dari segi pendapatan maupun perannya dalam rumah tangga. ${ }^{7}$

\section{Bentuk Ijtihad Responsif dalam Penegakan Hukum Positif Islam di Pengadilan} Agama

Studi tentang ijtihad responsif hakim Peradilan Agama tentang pengembangan Kompilasi Hukum Islam (KHI) khususnya tentang pembagian harta bersama sangat signifikan karena berkaitan dengan "hukum kasus" yang dihadapi para hakim agama, maka berkaitan dengan ini disebut juga "teori hukum kasus". Hukum yang akan diputus / ditetapkan oleh hakim masih dalam proses pembuatan, masih dicari. Pencarian tersebut melalui fakta-fakta dan peristiwa-peristiwa yang setelah terbukti dengan alat bukti yang sah barulah ditemukan dalam bentuk putusan/penetapan itu sendiri untuk kekuatan pastinya masih harus menunggu sampai mempunyai kekuatan hukum yang tetap (inkracht).

Fakta atau peristiwa yang melatarbelakangi sengketa/perkara, yang harus dibuktikan di Pengadilan Agama, adalah suatu yang telah terjadi, lalu hakim setelah memperhatikan segala yang berkaitan hubungannya mencarikan hukum yang paling tepat untuk kasus tersebut. Jadi tegasnya, hukum yang berlaku di pengadilan adalah hukum kasus, bukan hukum dalam "fungsi mengatur". Hukum kasus dibedakan

${ }^{7}$ Putusan Pengadilan Agama Rembang No. 433/Pdt.G/2007/PA. Rbg., tertanggal 12 Nopember 2007 M, bertepatan dengan tanggal 2 Dzul Qa'dah $1428 \mathrm{H}$. 
dengan hukum dalam fungsi mengatur, karena hukum dalam fungsi mengatur bersifat netral, lepas dari konteks fakta dan peristiwa.

Hukum kasus diistilahkan dengan ahkam nafs al-waqi' atau ahkam da'wa al-waqi', sedangkan hukum dalam fungsi mengatur diistilahkan dengan ahkam hifz al-huquq. Hukum kasus adalah untuk sengketa/perkara, sedangkan hukum dalam fungsi mengatur adalah hukum di luar sengketa. Adapun cara menemukan hukum materiil atas kasus di pengadilan, yakni melalui hukum acara atau pembuktian, dinamakan turuq al-ahkam, sedangkan cara menemukan hukum materiil di luar kasus perkara di pengadilan dinamakan hifz al-huquq. ${ }^{8}$

Dalam praktik Pengadilan Agama, untuk melihat kasus yang beragam, lebihlebih yang bersifat komulasi (hal mana sesuai dengan gugatan atau permohonan yang diajukan oleh pencari keadilan), maka pertama-tama hakim akan mendudukkan dahulu pokok perkaranya atau kasusnya (case position atau nafs alwaqi' atau da'wa al-waqi'). Setelah itu hakim akan melihat bagaimana hukum materiilnya (seperti Kompilasi Hukum Islam dalam bidang pembagian harta bersama) yang relevan bersifat umum dan khusus, baik yang tertulis maupun yang tidak tertulis untuk diukur dengan kasus tersebut. Kemudian hakim akan menarik kesimpulan sesuai bukti-bukti yang diajukan dan cocok dengan kasus tersebut.

Dalam hal ini, apabila dalam kasus yang bersifat komulasi hukum yang persis dengan kasus itu jarang ditemukan, yang dengan sendirinya membawa konsekuensi pula di segi pembuktiannya. Di sini letak kesulitan dan tanggung jawab hakim dalam menghubungkan fakta-fakta atau peristiwa, mendudukkan kasusnya serta mempergunakan pembuktian dan hukum yang relevan. Untuk itu dapat dikatakan bahwa hakim itu: "am an-nazari wa khas al-'amali". ${ }^{9}$ Dari sini dapat dinyatakan bahwa penerapan hukum kasus di Pengadilan Agama ternyata memerlukan wawasan hukum Islam yang sangat luas, tidak dan belum mencukupi dengan hanya menguasai hukum materiil Islam dalam perundang-undangan. Tanpa itu, menemukan hukum materiil dalam kasus, besar kemungkinan tidak mencerminkan keadilan hukum menurut Islam. ${ }^{10}$

Pembicaraan tentang pembentukan atau pengembangan hukum dalam ushul fikih disebut ijtihad, hal ini berkaitan erat dengan perubahan-perubahan sosial yang

\footnotetext{
${ }^{8}$ Roihan A. Rasyid, "Hukum Kasus dan Hukum dalam Fungsi Mengatur (Terapannya di Pengadilan Agama)", Mimbar Hukum No. 19 Tahun. VI 1995, hlm. 15.

${ }^{9}$ Ibid., hlm. 17.

${ }^{10}$ Ibid., hlm. 25.
} 
berlangsung dalam kehidupan masyarakat. Secara umum ijtihad itu dapat dikatakan suatu upaya berpikir secara optimal dalam menggali hukum Islam dari sumbernya untuk memperoleh jawaban terhadap permasalahan hukum yang muncul dalam masyarakat. ${ }^{11}$

Islam adalah agama terakhir bagi umat manusia. Setelah Nabi Muhammad SAW tidak ada lagi rasul yang diutus dan tidak ada pula wahyu yang diturunkan untuk mengatur manusia. Allah Maha Bijaksana dan Maha Mengetahui watak dan kebutuhan manusia ciptaan-Nya yang bersifat dinamis, realistis dan berkembang. Hal ini mengandung pengertian bahwa Islam yang dinyatakan sempurna di akhir hayat Rasulullah itu, benar-benar agama yang memiliki dinamika yang amat tinggi, mampu menampung segala macam persoalan yang ditimbulkan oleh perubahan dan perkembangan zaman. Dengan itu ajaran Islam dapat berlaku sepanjang masa dan perkembangan sosial, ${ }^{12}$ di sinilah terletak posisi penting dan relevansinya hakikat ijtihad.

Seorang hakim dalam menghadapi persoalan hukum yang kompleks dan dinamis, harus menguasai dua bentuk ijtihad, yaitu pertama ijtihad istinbati dan kedua ijtihad tatbiqi. Ijtihad hakim mengenai pengembangan hukum dari teks atau pedoman hukum yang ada seperti Kompilasi Hukum Islam(KHI) perlu dilakukan, dan ini merupakan amanah Pasal 229 KHI yang dinyatakan: "Hakim dalam menyelesaikan perkara-perkara yang diajukan kepadanya wajib memperhatikan nilai-nilai hukum yang hidup dalam masyarakat sehingga putusannya sesuai dengan rasa keadilan".

Hal ini merupakan dorongan kepada hakim agama untuk mengembangkan hukum Islam dalam hal ini pembagian harta bersama yang menjadi wewenang absolut Peradilan Agama dalam berijtihad, berupa: (1) melengkapi hukum yang belum ada dan menyempurnakan hukum (Kompilasi Hukum Islam) yang sudah ada, (2) undang-undang menentukan hal-hal yang umum, sedangkan pertimbangan hal-hal yang konkrit diserahkan kepada hakim untuk mengembangkan hukumnya, dan (3) ada kekosongan hukum yang harus diisi oleh hakim.

Hakim dalam menghadapi perkara yang diajukan kepadanya ditemukan perkara yang sama, tetapi nuansa dan subtansinya tidak sama, sebab berlainan subjek, kondisi maupun objek dan subjek yang melatarbelakangi tidak sama. Dari dua bentuk ijtihad hakim Peradilan Agama di atas secara ringkas dapat disimpulkan, bahwa: 1. ijtihad

\footnotetext{
${ }^{11}$ Asfari Jaya Bakti, Konsep Maqasid al-Syari'ah menurut Al-Syatibi dan Relevansinya dengan Ijtihad Hukum Dewasa ini, Program Pascasarjana IAIN Syarif Hidayatullah, Jakarta, 1994, hlm. 1.

${ }^{12}$ Satria Effendi M. Zein, "Ijtihad dan Hakim Peradilan Agama”, Mimbar Hukum No. 10 Tahun. IV 1993, hlm. 41.
} 
istinbati, yaitu berkenaan dengan: (a) penguasaan hukum secara tekstual, (b) upaya untuk melihat 'illat (alasan hukum) yang terkandung dalam nash atau hukum tekstual itu, (c) lalu menggali apa ide yang terkandung dalam nash atau hukum tekstual itu, (d) objek kajiannya adalah nash atau hukum tekstual itu, dan (e) penguasaan hukum Islam secara eksplisit; 2. ijtihad tatbiqi, yaitu berkenaan dengan: (a) hukum hendak diterapkan sesuai dengan ide yang terkandung dalam nash atau hukum tekstual itu, (b) menyangkut persoalan penerapan hukum dalam kasus yang kongkrit, (c) menerapkan ide yang terkandung dalam nash atau hukum tekstual itu, (d) objek kajian dalam ijtihad ini adalah manusia dan dinamikanya, dan (e) menyimpulkan semangat/ spirit/ruh nilai hukum dalam nash atau hukum tekstual itu.

Hukum pembagian harta bersama dalam Kompilasi Hukum Islam (KHI) termasuk hukum yang bersifat mengatur dalam fungsi undang-undang yang bersifat deduktif, tekstual dan normatif. Sedangkan perkara pembagian harta bersama yang diajukan kepada hakim agama bersifat kasuistis, induktif, kontekstual dan empiris, yang disebut hukum kasus. Berkaitan dengan hukum kasus di atas, Pasal 229 KHI mengemukakan bahwa: "Hakim dalam menyelesaikan perkara-perkara yang diajukan kepadanya, wajib memperhatikan sungguh-sungguh nilai-nilai hukum yang hidup dalam masyarakat, sehingga putusannya sesuai dengan rasa keadilan".

Aspek filosofis dalam pembagian harta bersama yang diajukan di Pengadilan Agama tidak dapat dilepaskan dari aspek keadilan. Keadilan merupakan tujuan hukum Islam dan banyak dalam al-Qur'an untuk menyuruh berbuat dan menegakkan keadilan. Sifat adil yang terkait erat dengan prinsip keadilan dalam hukum keluarga termasuk dalam pembagian harta bersama merupakan hal yang fundamental.

Berkaitan dengan hal ini, apabila dikaji mengenai hukum Islam dalam kontruksi pemikiran Fazlur Rahman, yaitu memahami ungkapan-ungkapan al-Qur'an untuk digeneralisasikan kepada prinsip-prinsip moral-sosial dengan cara mengaitkan ungkapan-ungkapan spesifik al-Qur'an beserta latar belakang sosio-historis dan dengan mempertimbangkan ratio-legis ('illat hukum) yang dinyatakan dalam ungkapan-ungkapan al-Qur'an dan selanjutnya adalah dengan merumuskan prinsip-prinsip umum tersebut ke dalam konteks sosio-historis aktual sekarang ini. ${ }^{13}$

Mempertimbangkan konteks sosio-historis aktual dalam pembagian harta bersama merupakan keniscayaan, sehingga timbul permasalahan hukum antara teks,

${ }^{13}$ Efrinaldi, “ Reaktualisasi Hukum Islam, Suatu Kajian Metodologis dalam Pemikiran Fazlur Rahman”, Mimbar Hukum No. 50 Tahun. XII 2001, hlm. 97. 
yaitu Pasal 97 KHI sebagai das solen dengan konteks sosio-historis sebagai das sein, hal ini menggambarkan konsep hukum Islam pada konstruksi pemikiran aplikasi di Pengadilan Agama dalam aspek hubungan kehidupan bermasyarakat khususnya antara suami dengan isteri dalam hal hukum ekonomi, lebih jelasnya hukum nafkah.

Kemungkinan adanya bahaya subyektivitas penafsir (seperti Kompilasi Hukum Islam) untuk menghindarkan atau setidaknya untuk meminimalkan bahaya subyektivitas tersebut, Rahman mengajukan sebuah metodologis yang terdiri dari tiga pendekatan, yaitu: ${ }^{14}$ pertama, pendekatan historis untuk menemukan makna teks. Kedua, pendekatan kontentual untuk menemukan sasaran dan tujuan yang terkandung dalam ungkapan legal-spesifik dan ketiga, latar belakang sosiologis untuk menguatkan hasil temuan pendekatan kontentual untuk menemukan sasaran dan tujuan yang tidak dapat diungkapkan oleh pendekatan kontentual atau disingkat dengan rentetan pendekatan: "historis, kontentual dan sosiologis".

Ide pokok yang terkandung dalam gerakan pertama, sebagaimana yang disebutkan di atas, adalah penerapan metode berpikir induktif, berpikir dari pasal KHI yang spesifik, menuju kepada prinsip atau dengan kata lain adalah berpikir dari aturan-aturan legal spesifik menuju kepada moral sosial yang bersifat umum yang terkandung di dalamnya.

Dengan demikian kedudukan hakim dalam penegakan hukum merupakan suatu nikmat yang agung, karena dengan itu keadilan Allah dapat ditegakkan di muka bumi. Begitu tingginya kedudukan hakim, tentu ada hubungannya dengan kemampuan untuk menegakkan keadilan. Apa yang dijanjikan oleh Allah SWT. dalam sebuah ayat al-Qur'an (QS. 5: 42) yang maksudnya: “Dan apabila engkau memutus suatu perkara, putuskanlah antara mereka secara adil, bahwa sesungguhnya Allah mencintai orang-orang yang berbuat adil". Hal ini dapat dipenuhi apabila terpenuhinya persyaratan untuk menduduki jabatan hakim, baik yang menyangkut moral maupun yang menyangkut kemampuan intelektual. ${ }^{15}$

Suatu hal yang mendasar dengan moral adalah kemampuan hakim untuk berbuat adil. Pengertian adil secara khusus dalam bidang ini diartikan sebagai kemampuan seorang hakim untuk menyelesaikan suatu perkara secara objektif. Adapun persyaratan adanya kemampuan intelektual, berarti bahwa seorang yang akan menjadi hakim perlu mempunyai kemampuan untuk berijtihad. Dengan

\footnotetext{
${ }^{14}$ Ibid., hlm. 103-106.

${ }^{15}$ Satria Efendi M.Zein, "Ijtihad Hakim Peradilan Agama”, dalam Mimbar Hukum No. 10 Tahun. 10 1993, hlm. 39.
} 
demikian, kedua aspek tersebut, yakni aspek moral dan aspek intelektual saling melengkapi dalam melaksanakan tugas seorang hakim. Keduanya antara aspek moral dan aspek kemampuan intelektual merupakan suatu kesatuan yang tidak dapat dipisahkan, apabila keduanya tidak saling menyatu mengakibatkan kepincangan dalam memutus suatu perkara yang diajukan kepada hakim yang menangani suatu perkara yang diajukan kepada hakim tersebut.

Dengan demikian, menurut ilmu hukum, ada tiga pandangan mengenai fungsi hakim, yaitu: ${ }^{16} 1$. pandangan dari aliran legisme, yaitu pandangan yang menyatakan bahwa fungsi hakim hanya melakukan pelaksanaan undang-undang saja dengan cara 'juridische sylogisme' yaitu suatu deduksi logis dari suatu perumusan yang luas (proposisi mayor) kepada suatu keadaan khusus (proposisi minor), sehingga pada kesimpulan; 2. pandangan dari 'freie rechts beweging', yang menyatakan bahwa hakim berfungsi menciptakan hukum, maka ia dalam melakukan fungsinya tersebut tidak harus terikat oleh undang-undang; 3. pandangan dari 'rechts vinding', yaitu menyelaraskan undang-undang pada tuntutan zaman.

Dalam menerapkan peraturan perundang-undangan, terlebih dahulu hakim harus menafsirkan peraturan perundang-undangan (dalam hal ini Kompilasi Hukum Islam). Menurut ilmu hukum ada 3 aliran dalam menafsirkan peraturan perundang-undangan, yaitu: ${ }^{17} 1$. aliran tekstual, yaitu cara menafsirkan peraturan perundang-undangan, pertama-tama dengan mengerahkan usaha untuk mengetahui kehendak hakiki dari pembuat undang-undang itu. Untuk itu dapat digunakan teknik tafsir gramatika, sistematis, historis dan utility. Kemudian apabila tidak terdapat ketentuan yang mengatur kasus yang dihadapi hakim, maka ia memperkirakan sikap pembuat peraturan perundang-undangan apabila dihadapkan masalah tersebut; 2. aliran kontekstual atau historis, yaitu cara menafsirkan peraturan perundang-undangan sesuai dengan perkembangan sosial, politik dan ekonomi, ketika penafsiran dilakukan dan bukan dengan jalan memperkirakan kehendak pembuatnya, tetapi berpegang pada kehendak yang mungkin pada pembuatnya; 3. aliran ilmiah, yaitu cara menafsirkan dengan: (a) berpegang pada teks, (b) apabila yang pertama tidak dapat dilaksanakan, maka berpegang pada sumber hukum lainnya yang sah, dan (c) apabila yang kedua tidak

\footnotetext{
${ }^{16}$ Taufiq, "Ijtihad Hakim Agama", Makalah Disampaikan pada Seminar Nasional Hukum Islam dan Perubahan Sosial, di Semarang, Oktober 1990, hlm. 3.

${ }^{17}$ Ibid., hlm. 6.
} 
dapat dilaksanakan, maka berpegang pada inti dari peraturan perundang-undangan serta sumbernya dan faktor-faktor yang mempengaruhi sehingga lahir norma hukum.

Dari aliran dalam menafsirkan peraturan perundang-undangan di atas, hakikatnya adalah upaya untuk melakukan ijtihad dalam penerapan keadilan, dengan demikian hakim pada Pengadilan Agama dalam melakukan fungsinya, yaitu berupaya melakukan 'social engeneering' sekaligus mempertahankan 'social order'.

Upaya ijtihad hakim Peradilan Agama dalam penerapan hukum dalam suatu kasus disebut ijtihat tatbiqi. Ijtihad ini tidak pernah putus sepanjang masa, selama umat Islam bertekad baik untuk menerapkan ajaran Islam ke dalam kehidupan. Untuk itu pada diri seorang hakim agama harus menguasai dua kemampuan, yaitu kemampuan untuk menguasai hukum yang berkaitan dengan 'ijtihad istinbati' dan kemampuan untuk menerapkannya dalam suatu kasus yang ditanganinya disebut 'ijtihad tatbiqi'.

\section{Penutup}

Berdasarkan uraian di atas dapat disimpulkan bahwa, wujud penegakan hukum positif Islam di Pengadilan Agama untuk mewujudkan keadilan dalam pembagian harta bersama dalam Kompilasi Hukum Islam (KHI) adalah isteri mendapatkan 2/3 (dua pertiga) lebih besar dibanding dengan suami yang mendapatkan $1 / 3$ (sepertiga), karena dipandang proporsional dan adil apabila terhadap harta bersama tersebut dibagi berdasarkan seberapa banyak kontribusinya dalam menghasilkan harta bersama tersebut dan ternyata isteri dalam menghasilkan harta bersama tersebut kontribusinya lebih besar dibanding dengan suaminya. Putusan ini seolah-olah bertentangan dengan Pasal 97 KHI dan putusan ini merupakan pengembangan KHI (tahrij al-ahkam 'ala nashil qanun) dalam upaya menjawab hukum kasus yang berkeadilan.

Bentuk ijtihad responsif dalam penegakan hukum positif Islam di Pengadilan Agama untuk mewujudkan keadilan dalam pembagian harta bersama dalam Kompilasi Hukum Islam (KHI) adalah dengan ijtihad tatbiqi, yaitu ijtihad dalam penerapan hukum dengan melihat hukum kasus atau 'hukum kasuistis' dengan melihat fakta atau peristiwa yang melatarbelakangi sengketa atau perkara, lalu hakim setelah memperhatikan segala hubungan keterkaitannya langkah berikutnya mencarikan hukum yang tepat untuk kasus tersebut. 
Karena yang dihadapi oleh hakim Peradilan Agama itu hukum kasus, maka sebagai penegak keadilan harus melakukan ijtihad membuat putusan yang tepat/ cocok dengan kasus yang terjadi itu dengan mempertimbangkan nilai filosofis (keadilan) dan sosiologis (kemanfaatan), tidak semata-mata nilai yuridis (kepastian) huukum.

Karena kehidupan sosial ini dinamis, dan selalu berubah, maka hukum selalu ketinggalan dari perubahan itu. Hal ini merupakan dorongan kepada hakim Peradilan Agama untuk melengkapi hukum yang belum ada dan menyempurnakan hukum (Kompilasi Hukum Islam) yang sudah ada.

Karena undang-undang menentukan hal-hal yang umum, maka hakim harus mempertimbangkan hal-hal yang konkrit untuk mengembangkan hukumnya dan hakim harus mengisi kekosongan hukum untuk menjawab hal-hal yang konkrit itu.

\section{Daftar Pustaka}

A. Rasyid, Raihan, “Hukum Kasus dan Hukum dalam Fungsi Mengatur (Terapannya di Pengadilan Agama)", dalam Mimbar Hukum No. 19 Tahun. VI 1995.

Efrinaldi, "Reaktualisasi Hukum Islam, Suatu Kajian Metodologis dalam Pemikiran Fazlur Rahman", dalam Mimbar Hukum No. 50 Tahun. XII 2001.

Effendi M. Zein, Satria, "Pendidikan Syari'ah di IAIN dan Pembinaan Sikap Independen dalam Hukum Islam", dalam Mimbar Hukum No 11 Tahun. IV 1993.

, "Ijtihad Hakim Peradilan Agama", dalam Mimbar Hukum No. 10 Tahun. IV 1993.

Hanityo Soemitro, Ronny, Metodologi Penelitian Hukum, Cet. 1, Ghalia Indonesia, Jakarta, 1982.

Jaya Bakti, Asfari, Konsep Maqashid al-Syari'ah menurut Al-Syatibi dan Relevansinya dengan Ijtihad Hukum Dewasa ini, Program Pascasarjana IAIN Syarif Hidayatullah, Jakarta, 1994.Khisni, A., Transformasi Hukum Islam ke dalam Hukum Nasional (Studi Ijtihad Hakim Peradilan Agama tentang Pengembangan Hukum Kewarisan dalam Kompilasi Hukum Islam dan Kontribusinya terhadap Hukum Nasional), Program Doktor Ilmu Hukum UII, Yogyakarta 2011.

- Metode Ijtihad dan Istinbath, Ijtihad Hakim Peradilan Agama, Cet. 1, Unissula Press, Semarang, 2011.

Taufiq, Ijtihad Hakim Agama, Makalah Disampaikan pada Seminar Nasional Hukum Islam dan Perubahan Sosial, di Semarang, Oktober 1990. 
Tholabi Kharlie, Ahmad, "Al-Syaukani: Profil Pembaru Pemikiran Hukum Islam”, dalam Mimbar Hukum No. 53 Tahun XII 2001.

Putusan Pengadilan Agama Yogyakarta No. 280/Pdt.G/2002/PA.Yk. tertanggal 16 September 2003 M., bertepatan dengan tanggal 19 Rajab 1424 H. Jo. Putusan Pengadilan Tinggi Agama Yogyakarta, No. 36/Pdt.G/2003/PTA. Yk, tanggal 21 Januari $2004 \mathrm{M}$. bertepatan tanggal 30 Dzulqo'idah $1424 \mathrm{H}$. Jo. Putusan Mahkamah Agung RI No. 193 K/AG/2004, tanggal 21 Pebruari 2007.

Putusan Pengadilan Agama Rembang No. 433/Pdt.G/2007/PA.Rbg, tertanggal 12 Nopember 2007, bertepatan dengan tanggal 2 DzulQa'dah 1428. 